\title{
Miranda
}

Revue pluridisciplinaire du monde anglophone /

Multidisciplinary peer-reviewed journal on the English-

speaking world

23 | 2021

Modernist Exceptions

\section{Exceptionality and the unexceptional in Jean Rhys's interwar fiction}

\section{Juliana Lopoukhine}

URL: https://journals.openedition.org/miranda/42364

DOI: 10.4000/miranda.42364

ISSN: 2108-6559

\section{Publisher}

Université Toulouse - Jean Jaurès

\section{Electronic reference}

Juliana Lopoukhine, "Exceptionality and the unexceptional in Jean Rhys's interwar fiction", Miranda

[Online], 23 | 2021, Online since 12 October 2021, connection on 29 November 2021. URL: http:// journals.openedition.org/miranda/42364 ; DOI: https://doi.org/10.4000/miranda.42364

This text was automatically generated on 29 November 2021.

\section{(c) (i) () $\Theta$}

Miranda is licensed under a Creative Commons Attribution-NonCommercial-NoDerivatives 4.0 International License. 


\title{
Exceptionality and the unexceptional in Jean Rhys's interwar fiction
}

\author{
Juliana Lopoukhine
}

1 In her five-hundred-page volume on women modernist writers, Shari Benstock calls Jean Rhys an "outsider among outsiders" (Benstock 448). And the paradox is that this definition, or rather anti-definition, might very well be Rhys's most consensual feature. Indeed, when it comes to Jean Rhys, a white creole woman writer born in the West Indies, but who was sent away to Europe at the age of sixteen to earn a living as a chorus-girl, her being an exception in every way is indeed the one point on which critics across generations and academic fields come to an agreement. In fact, an ongoing historiographical debate has been opposing postcolonial and modernist critics who have claimed her as their "own", yet with notable dissensions within each field. The fiery debate has even led Elaine Savory to write that, like Helen of Troy, Jean Rhys was "stolen or kidnapped from the Caribbean by Western literary taste, and as a white writer, as the symbolic white woman, is particularly desired by Europe" ${ }^{1}$ (Savory 1998, 216).

2 Yet this statement raises one more paradox: Rhys's relative absence from the charts of modernist criticism until quite recently remains a critical slight inexplicable to many. ${ }^{2}$ Johnson and Moran, in the introduction of their recent collective volume on Jean Rhys, wonder at Rhys's marginal position in the Modernist canon, "[d]espite the fact that she published a book of short stories and four novels between 1927 and 1939, and despite her masterful experimental form and contributions to the aesthetic and thematic explorations of her contemporaries" (Johnson and Moran 6). True, the issue of Jean Rhys's perpetual "unbelonging" is further problematized by the heterodox context of Modernism, in which allegedly each individual writer, though influenced by others, experimented in a unique way against a set of established literary norms. Her oscillation between postures of inclusion and exclusion within critical fields, her gender and West Indian identity, are further complicated by her own ambivalence 
towards any establishment or group that might force her into some kind of belonging. If, arguably, all experimental writers escape categories, as a white creole woman compelled to live in the heart of the Empire, Jean Rhys did so in a singular manner. ${ }^{3}$ Indeed, Mary-Lou Emery sees Rhys's three critical identities as mutually exclusive when it comes to labelling her, thus making her an exception in feminist, postcolonial and modernist studies alike. Each identity, she argues, is constructed "outside the main current by reason of its participation in the other two" (Emery 1990, 8). The only remaining path with Rhys, Emery writes, lies in "crosscurren[t]" approaches. Indeed, Rhys's "unique contradictions" (Savory 1998, 223) seem to leave her scholars no other choice but to give up trying to "place" her.

Rhys's strangeness and eccentricity have been largely emphasized by biographical as well as narrative criticism, sometimes leading to a confusion between the two. Yet the sense of unbelonging she expresses in her fiction has rightly been interpreted as stemming from her own estrangement from European values. Indeed, most of her short stories and novels feature characters at odds with their environment, both unable to comply with, and excluded by, a repressive moral code generated by power structures, and resisting dissolution into a unifying norm. At the same time, however, one of the ways in which Jean Rhys negotiated this out-of-placeness in relationship to a norm is, paradoxically, through a mode of writing that forcibly insists on the unexceptional, understood as the same, the ordinary, the insignificant. Through her characters' laconic, jaded, disenchanted voices, she explores "a kind of modern consciousness" (Carr 17) that is inseparable from what Iain Chambers calls the "oblique view of the migrant" (qtd. Carr 25).

Despite being included in a special issue on modernist exceptions, the present study does not seek to claim Jean Rhys for the "modernist" side of the war. Rather, by considering Jean Rhys's contribution to modernism within the complex context of her Caribbean identity, and following Jessica Berman's urge to consider the "stylistic experimentation as a spur to new possibilities of [political] engagement" (Berman 2006, 465), it seeks to contribute to the current scholarly discussion about, and subsequent reshaping of, the temporal and cultural boundaries of modernism. ${ }^{4}$ I will argue that Jean Rhys's "strangeness" ${ }^{5}$ has been responsible both for her being excepted from the canon of Modernism for so long, and for the strong appeal of her work since her rediscovery in the 1960s. By examining the "strange" insistence on the unexceptional in three of her four interwar novels, After Leaving Mr Mackenzie (1930), Voyage in the Dark (1934) and Good Morning, Midnight (1939), I will argue that Jean Rhys's modernist aesthetics forges a new experimental use of the English language from the eccentric position of the outsider. ${ }^{6}$

\section{Historiography and the modernist canon: the strange case of Jean Rhys}

5 The "unusual" or "strange case" of Jean Rhys, as Peter Kalliney calls it in the 2012 Oxford Handbook of Global Modernisms (Kalliney 420-429), is first and foremost a story of exclusion. Stories about how gender and cultural stereotypes have excluded women from an originally Eurocentric modernist canon shaped mostly by male critics are now well-known, such as Al Alvarez's 1972 definition of Rhys as both "best living novelist" (qtd. Carr 4) and "non-intellectual" (qtd. Carr 10). ${ }^{7}$ A few years later, the now infamous, 
reductive archetype "Rhys woman", a passive, helpless victim of masculine domination, was used to categorize all her female characters, seen as being modelled after a type. One of her early critics even supposed her to be "unaware of or removed from many of [modernism's] preoccupations" (Staley qtd. by Maurel 6). Because she never really mingled with the literary and artistic circles of Montparnasse during the time that she spent in interwar Paris, she appeared to some critics as "a ghost among the expatriates" (Benstock 450).

6 In light of such exclusion, the fact that Rhys's excellence as a modernist writer was famously acknowledged by Ford Madox Ford in his preface to her first collection of short stories in 1927 might appear as one more paradox out of the many that surround Jean Rhys's reception. The patron of the Left Bank expatriates and editor in chief of the Transatlantic Review paid a warm tribute to "her very remarkable technical gifts" (Ford 147-148), writing: "Miss Rhys's work seems to me to be so very good, so vivid, so extraordinarily distinguished by the rendering of passion, and so true" (Ford 149-150). Despite the patronizing, self-promoting, falsely modest tone of Ford's prose, which contrasts so strongly with Jean Rhys's own style, his admiration for her literary gift is expressed in enthusiastic, almost bombastic exclamations, to the extent of venturing to prophesize the translation of her ashes to the Pantheon, fantasizing about her having gained such hyperbolic fame as to actually make her deserve the quintessential literary consecration (150). More notably perhaps, what he saw as strikingly unique was what he called her "singular instinct for form", "possessed by singularly few writers of English and by almost no English women writers" (148).

Despite the characteristically gendered reading of the canon, Ford is still registering here the emergence on the literary stage of a gifted new young writer, endowed with some unique abilities, and is explicitly weighing her skills against those of her contemporaries whose works he published in the Transatlantic Review, among which featured such renowned modernist writers as Ernest Hemingway, James Joyce or Gertrude Stein. Despite the alleged partiality due to the affair Ford had with Jean Rhys in 1924-25, he is not the only critic to have recognized Rhys's skills as early as the interwar period: Elaine Savory writes that Frank Swinnerton commented in a 1939 issue of The Observer that "he found the crafting of [Good Morning, Midnight] 'quite exceptional"' (Savory 1998, 200). However, instead of bringing her the expected recognition and fame, her first four novels, written between 1927 and 1939, were not read or acknowledged in modernist European circles, but rather by a small readership that appreciated them mainly for their social critique (Carr 2), calling them "sordid but artistic", they were completely forgotten in the post-war context of the 1950s, in which the topics of her fiction were deemed too depressing.

Strikingly enough, even though the BBC broadcasting of Good Morning, Midnight in 1957 gave her the necessary encouragement to carry on with her writing, it was really her 1966 novel Wide Sargasso Sea that gave her a place as a modernist writer, by bringing her the recognition she had failed to gain during the modernist period itself. ${ }^{8} \mathrm{Her}$ four interwar novels were then rediscovered retrospectively, and this eventually led critics to start reading them as experimental texts within the context of modernism. However ambiguous, and frustrating, it may appear to the modernist scholar, it is indeed thanks to what remains her most famous novel, as well as an emblem of postcolonial literature, that Rhys is currently being slowly included into the modernist canon. ${ }^{9} \mathrm{Had}$ she never completed Wide Sargasso Sea, which took her about twenty years to write, and 
whose fate at one point depended on just two undictated sentences, she would probably not even be considered as a "modernist exception" today. ${ }^{10}$

Yet while Jean Rhys acquired the status of an acknowledged writer at last, she also started her career as "the symbol of a cultural battle" (Savory 1998, 216)-or perhaps the plural "battles" would be more accurate: firstly, between those who have considered her a Caribbean writer and those who question her belonging to that field. ${ }^{11}$ Secondly, between those who "read only a European modernist Rhys", thus "excis[ing] her Caribbean context" (Johnson and Wilson 5) and those who claim her as a postcolonial "writer back". In the middle of all the paradoxes that surround Jean Rhys, her "multiple and divided identities" (Carr 18), the impossibility of categorizing her, the mishaps and twists in the transmission of her work, what remains is a series of oxymorons coined by those among her critics who have not given up on the task of reading her without trying to force her into labels, while accepting that she is forever "unplaceable", because of her complex, ever marginal identity, because she was a "riddle" who never "[explained] herself" (Naipaul), and because of her own active selfmarginalisation, through ambivalent attitudes. ${ }^{12}$ Although she yearned for the recognition of her peers, as she retrospectively wrote in her letters, she mostly avoided acquaintance with them, later nicknaming her fellow expatriate writers "America in Paris", "England in Paris", "not Paris at all", or even using the more derogatory "tourists" (Letters 280).

Her "productive" paradoxes (Savory 1998, 222), her "persistently marginal canonicity" (Johnson and Moran 4) and enduring status as a perpetual exception leave her at the margins of the canon and give her a unique place within it. It is striking to note that the past decade has shown an unrelenting interest in, and even fascination for, Jean Rhys's work: in the wake of Elaine Savory's Cambridge Introduction to Jean Rhys (2009), in which Rhys is called "irresistible" (Savory 2009, xi), no less than four edited volumes and several new monographs were published on her oeuvre; Helen Carr's 1998 monograph was reissued; two conferences were held on her work, one in London and one in Paris; two journal issues were devoted exclusively to her; Caryl Phillips' latest novel, A View of the Empire at Sunset, is based on Jean Rhys's life.

11 And indeed, when V.S. Naipaul wrote in a 1972 issue of The New Yorker that "she was an expatriate, but her journey had been the other way round" (Naipaul 1972), he also implied that Jean Rhys's exclusion, or self-exclusion, might in fact well be the source of her very exceptionality as a writer. "What really matters is her strangeness", says Mary-Lou Emery about the enigma posed by Jean Rhys to her readers (Emery 2013, xi). What if "strangeness", understood as what is incongruous, unusual, perhaps disturbing, as well as the foreignness of the mongrel who is always an exception, was in fact the very source of Jean Rhys's appeal?

\section{The unexceptional as an idiom of exception}

12 It seems paradoxical that a writer who has been so insistently branded with "tropes of otherness" by her critics (Carr 14) should at the same time make such an insistent use of tropes of "sameness" in her writing. What I want to bring under scrutiny in this study is not so much the absence of anything exceptional, of anything extraordinary, or remarkable, of any event in the traditional sense of the word, or of any hero, which arguably has been a common characteristic among modernists, but rather the repeated 
emphasis and almost obsessive insistence on repetition and monotony, as well as, to some extent, the deliberate erasure of out-of-the-ordinary emotional expression. In Voyage in the Dark, the jaded tone and sense of monotony spring essentially from the first-person narrator Anna Morgan's uprooting and constant longing, from the heart of cold and drab England, for the Caribbean island she had to leave and to which the narrative keeps returning, which generates a constant sense of placelessness. After Leaving Mr Mackenzie and Good Morning, Midnight, while being more rooted in the cosmopolitan city and less and less directly influenced by Jean Rhys's Caribbean background, are fraught with the characters' radical sense of unbelonging and emotional distance that pervade Jean Rhys's experimental modes with time and space.

In a passage of Good Morning, Midnight, the last of Jean Rhys's interwar works, and possibly her most emblematic "modernist" novel, Sasha Jansen slowly slides into a subjective and protective "indifference" that helps her live on after the traumas of her past:

Sometimes it's quite alright, sometimes it works. Often it works. And days. And nights. Eat. Drink. Walk. March. Back to the hotel. [...] Back to the hotel without a name in the street without a name. You press the button and the door opens [...] and the clients have no names, no faces. [...] Always the same stairs, always the same room. (Good Morning, Midnight, 120)

Under the effect of disenchantment, time becomes a long succession of indifferent days in which places and people fail to gain subjective or affective definiteness, or even a name. ${ }^{13}$ Jean Rhys's abundant use of the conjunction "and", and of the adverbs "sometimes", "always", "perpetually", creates a sense of temporal stasis and automatic routine that throws a veil of uniformity on her writing.

The pages of Rhys's 1934 novel, Voyage in the Dark, are notably splashed with the vivid colours of the Caribbean. However, an insistence on nameless, interchangeable places also appears, in contrast, when it comes to representing England: "all the houses outside in the street were the same-all alike, all hideously stuck together-and the streets going north, east, south, west, all exactly the same." (Voyage in the Dark, 89) In Jean Rhys's 1934 novel, the lack of colour, flavour and warmth of England is explicitly opposed to the vivid colours of the island she left behind, as Anna Morgan moves to England to earn a living as a chorus-girl: ${ }^{14}$ "Everything was always so exactly alike-that was what I could never get used to. And the cold; and the houses all exactly alike, and the streets going north, south, east, west, all exactly alike." (VD 152) As the character travels towards the capital city, which is also the centre of the Empire, what appears as strange and other to the uprooted stranger is, paradoxically, not the exotic, disorienting vision of an unfamiliar place, but rather the monotonous succession of identical sights that seem to tolerate no exception amid their uniformity: "This is London [...] a small, tidy look it had everywhere fenced off from everywhere else [...] smaller meaner everything is never mind-this is London [...] and the dark houses all alike frowning down one after the other all alike all stuck together" (VD 15-16). The frequent repetition of the phrase "all exactly alike", with variations, "all alike", ${ }^{15}$ emphasizes the violence experienced by the uprooted character thrown into a strange land, who, instead of defining herself as a marginal, rather perceives her environment critically as one that admits no exception among its ranks, because it is so "alike", something that she, as a misfit from the colonies, can never be. ${ }^{16}$ 

to circular temporalities that keep bringing them back to their initial position, or keep them at a narrative and geographical standstill despite their constant movement: "It's as if you had always done that-lived in a few rooms and gone from one to the other." (VD 121) In cities that are sometimes represented as a maze, the characters seem to constantly go back to where they had started: "She felt that her life had moved in a circle. Predestined, she had returned to her starting-point" (After Leaving Mr Mackenzie 48). ${ }^{17}$

In Good Morning, Midnight, Sasha Jansen forbids herself any kind of "excitement" (GMM 14) and declares that her

life, which seems so simple and monotonous, is really a complicated affair of cafés where they like me and cafés where they don't, streets that are friendly, streets that aren't, rooms where I might be happy, rooms where I shall never be, lookingglasses I look nice in, looking-glasses I don't, dresses that will be lucky, dresses that won't, and so on. (GMM 40)

"And so on" sounds like the perfect metatextual, metanarrative definition of Jean Rhys's experimental writing, and of her "simple and monotonous" temporality. ${ }^{18} \mathrm{Her}$ characters seem to be performing what Maurice Blanchot, in his discussion of the "neutral", calls the "immobile movement" of the everyday (Blanchot 241). Blanchot's enigmatic concept of the "neutral" refers not only to a grammatical category, or to a mere equivalent of negation, but also to a posture of withdrawal that resists any form of assertiveness or closure, "an anonymous, distracted, deferred, and dispersed way of being in relation" (Blanchot xii). Indeed, that "ambiguous existence" in which "nothing happens" but which "remains undecided in a disquieted quietude" (Blanchot 241), can be felt with particular acuteness in After Leaving Mr Mackenzie, when the monotony turns into an aimless movement of walking back and forth between four walls: "But on some days her monotonous life was made confused and frightening by her thoughts. Then she could not stay still. She was obliged to walk up and down the room" (ALM 9).

The "immobile movement" that often characterizes Jean Rhys's fiction and which Claire Joubert has evocatively compared to a broken record (Joubert 195) never gets more strikingly paradoxical than when it comes to the characters' experience of the emblematic cities that compose the setting of her interwar novels, especially Good Morning, Midnight and After Leaving Mr Mackenzie. The latter starts in Paris, then its character Julia Martin travels to London, and the novel ends back in Paris, having effectively "moved in a circle" (ALM 48). The cities of Paris and London, which, especially in the 1920s and 1930s, were highly emblematic places, perhaps even the epitome of exceptionality celebrated by generations of writers, mostly appear as a continuous expanse of inhospitable, grey and gloomy streets, rooms and cafés under Jean Rhys's pen. ${ }^{19}$ Her experience of the modern city, which bears no resemblance to the famous euphoric London stroll at the beginning of Virginia Woolf's Mrs Dalloway, remains one of survival, which her characters see through the filter of the same neutral "everyday indifference" (Blanchot 239). When Sasha Jansen, in Good Morning, Midnight, compares European cities and notes some of their idiomatic features, it is trivial details she dwells on, such as lavabos: the ones in Florence with the "fantastically dressed girls", the "cosy" ones in Paris, the ones in London with the disciplined women queuing and "clutching" their pennies (GMM 10). When she notes anything out of the ordinary, it is ironical: "the biggest bed in the world, the bed of beds" (GMM 67). On the other hand, what should be truly extraordinary, like a café where people pay to take naps 
instead of food, is presented as "rather interesting" and, when she visits it again, turns out to be as "empty, dead as a door-nail" (GMM 35).

Although Jean Rhys repeatedly confessed her love for Paris in her correspondence and her unfinished autobiography, in which she opposed it to her dislike of England-"I never once thought this is beautiful, this is grand, this is what I hoped for, longed for. [...] Then, why did I feel it in Paris?" (Smile Please 168-169)-it does not reflect unequivocally in her novels, in keeping with Rhys's refusal of the idea that her fiction is autobiographic. ${ }^{20}$ In fact, both cities appear as almost equally unexceptional places, to the exception of a few side remarks in Good Morning, Midnight. ${ }^{21}$ However, almost no expression of admiration for Paris is ever full-hearted in Rhys's fiction, and is almost immediately undermined by the characters' jaded tone, as when Sasha Jansen's tasting of the air that is "so sweet, as it can only be in Paris" is immediately followed by the melancholic image of autumn "dry leaves [...] blowing along" (GMM 26). She acknowledges that Paris has changed since her last visit, but immediately qualifies her statement, "But I don't believe things change much really; you only think they do. It seems to me that things repeat themselves over and over again." (GMM 56) During her peregrinations in the city, what she records is mostly tiredness, which is yet another form taken by Blanchot's "neutral", "I am not sad, but by the time I get back to the Boulevard Saint Michel I am feeling tired. I have walked along here so often, feeling tired." (GMM 39)

21 In After Leaving Mr Mackenzie, the character's subjective alienation to her environment is perhaps still more radically felt than in other novels by Rhys. Julia Martin meanders erratically in a state of emotional anaesthesia that paradoxically carries "difference even to the point of indifference" (Blanchot 305) as she identifies the emblematic places of the city without any possible emotional identification with them: "'Somewhere near the Halles,' she thought. [...] [S]he felt nothing. Now she felt indifferent and cold, like a stone." (ALM 136) The same happens in London, where Julia walks for hours with her eyes fixed "on the ground": "a puff of wind blew capriciously before her a little piece of greasy brown paper, omnibus tickets, a torn newspaper poster, coal dust, and dried horse dung." (ALM 84) Just as Sasha Jansen's detailed depiction of lavabos, instead of marvelling at the exceptional spectacle of the city as required of the traditional flâneur, Julia Martin's eyes are set on the trash randomly blown by the wind, without interrupting her aimless walking. Neither city ever becomes a distinct place, except, ironically, when Mr Mackenzie, Julia's former lover, fears that her erratic behaviour might lead to public scandal: "Assault. Premeditation could be proved. She wouldn't get away with it, not even here in Paris." (ALM 26)

The reader's expectations of a novel set in 1930s Paris or London are, to a large extent, thwarted by the irreverence of Jean Rhys's characters in front of the symbolical places whose historical value and exceptionalism, understood as self-proclaimed superiority, they refuse to acknowledge. In that respect, the account of Jean Rhys's first time in London with her aunt, in her autobiography Smile Please, while the latter shows her "the sights", is emblematic. To her aunt's dissatisfaction, the young Rhys doesn't see anything extraordinary in the sight of sights, Westminster Abbey: “I don't know what reaction she expected, but I know that I disappointed her. [...] 'Don't you know it's wonderful?' she said." (SP 100) By withdrawing herself from the injunction to acknowledge the imperialistic grandeur ("don't you know it's wonderful?" emphasis mine), an unobtrusive undermining of the edifices that have come to symbolize the 
political power of the imperial city takes place, not through blatant criticism, but simply by not paying it due attention and respect. In 1979, aged Jean Rhys stages her younger self, who, having lost her own geographical roots, has gained instead an outsider's position that allows her to give an indirect yet subversive nudge to the buildings that are the pride of an Empire which at the time held her island in its grasp.

\section{Rhys's eccentric aesthetics of the unexceptional}

Rachel Bowlby reads the "undifferentiation" in Rhys's fiction as a "narrative principle [...] that extends to objects, places, times and to the phrases which mark them out in their flat resemblances" (Bowlby 38). What I have defined as the "neutral" in Jean Rhys's novels concerns not only an emphasis on the unexceptional, the ordinary, the peripheral, the insignificant, in themes, objects, places and people. In fact, the "halfand-half" principle that rules Sasha Jansen's life in London (GMM 95), I argue, also extends to the use Rhys makes of language itself, which becomes a "literary act that belongs neither to affirmation nor to negation" (Blanchot 304). Jean Rhys's treatment of the English language wields a discretely subversive power, both as part of the modernist project that targets conventional forms of expression, and, in Jean Rhys's case, because it is the language of imperialism and hegemony. Following Elaine Savory's urge to consider the political dimension of Jean Rhys's writing (Savory 1998, 198), I argue that Jean Rhys's laconic tone, which has become her signature, appears as a minimal yet active mode of resistance to hegemonic discourses and representations. The minimalism, both semantic and syntactic, which characterizes Rhys's aestheticsthe blanks on the page, the excessive use of the conjunction "and", although arguably she was not the only modernist to have used such tropes-in her case might in fact be read as stemming from a critical vision of an imperialistic language and subsequent culture which tolerate no exception, and fail to recognize the exceptional status of the misfit. $^{22}$

Indeed, the eccentric existences of Sasha Jansen, Julia Martin and Anna Morgan find themselves the repeated objects of disparaging comments, either real or imaginary, on behalf of waiters, landladies, doctors, stepmothers, and, ultimately, those critics who have read her characters as a generic type, a passive and helpless victim termed the "Rhys woman". What those voices have in common is a fear of what does not fit their own moral and social categories, and an inability to acknowledge and make room for what is an exception to a norm described by Rhys on several occasions in her oeuvre as a certain "respectability" supported by the English ideology of the "lady", which both excludes and seeks to absorb those who fail to abide by its rules. As threats to the symbolic order, Rhys's characters are forced back into categories: "Faites comme les autres" (GMM 88), Sasha Jansen is told and repeats herself. Yet the ironical undertone, as well as the use of French language, point to a certain distance that enables her to redefine her identity as that of an exception who will never fit. By disappointing those expectations, and disorienting the reader, Jean Rhys's characters quietly distance themselves from the uniforming gaze and discourse they can never satisfy. In the same way, Jean Rhys's economical, and even minimal use of the English language, her "trimming" of any descriptive matter, which was noted by Ford in 1927, and which can be seen as a characteristic she shared with other modernist writers such as the Imagists, or Ernest Hemingway, ${ }^{23}$ might be read in her case not only as a feature of her 
modernist experimentation with form, but also as a sign of quiet reluctance, or reserve, when it comes to exploiting the full semantic and syntactic potentialities of the English language. Indeed, hers is a poetics of subjective loss and substraction transformed into a loss in language that has gained a dissident power.

In this light, the cliché of so-called universal wisdom quoted ironically by Sasha Jansen in the first pages of Good Morning, Midnight, "one mustn't put everything on the same plane. That's the great phrase" (GMM 12), appears as a metanarrative prescription..$^{24}$ In fact, it sounds like an instruction on how to organize and make a good story, which Jean Rhys deliberately ignores, and even contradicts, in her own narrative mode, that, in Rachel Bowlby's terms, could be described as the art of making "unstories" (Bowlby 35). In the remainder of this essay, I would like to focus on two devices through which her eccentric use of language avoids adopting exceptionality as an organizing element that would restore hierarchy into her writing: namely, enumeration and repetition.

Enumeration frequently replaces description as we know it, particularly with rooms and their content: a laconic inventory merely records whatever random objects stand or lay there: "There were only a sheet and a thin counterpane on the bed. [...] There was a spot on the ceiling" (VD 108). No place "of one's own", and no story, can take shape in a space in which nothing stands out. ${ }^{25}$ Through the combined use of bare deictics ("there was", "there were") and parataxis, Jean Rhys effectively "puts everything on the same plane", without any syntactic or semiotic hierarchy. "And one mustn't put everyone on the same plane either. Of course not", Sasha comically reminds herself. (GMM 12) Indeed, just like the random objects in the rooms, the people in Jean Rhys's "European" novels also appear as a list of chance encounters, all interchangeable. The men who, in After Leaving Mr Mackenzie, and to some extent in Voyage in the Dark, give the characters money, and stand for male, white, hegemonic power, are just as interchangeable as the hotel landladies who seem to be all modelled after one archetype. This is made clear in the table of contents of After Leaving $\mathrm{Mr}$ Mackenzie, in which some chapters are entitled after a place in the city, whereas some bear the names of men whose money Julia relies on to survive, all of them interchangeably put "on the same plane": "Part I: 1 . The Hotel on the Quay/2. Mr Mackenzie/3. Mr Horsfield"; "Part II: 3. Uncle Griffiths/4. Café Monico/5. Acton/6. Mr James". Conversely, in Good Morning, Midnight, the characters that Sasha Jansen meets in Paris appear as a gallery of marginal beings like her, compiled as a string of anecdotes rather than truly playing a part in the narrative. Scott McCracken writes that " $[\mathrm{t}] \mathrm{he}$ anecdote is one of the few narrative forms available to the defeated, who, in their condition of homelessness, have been separated from the narrative structures, whether historical or literary, that might otherwise sustain them" (McCracken 46). As fundamentally homeless beings, the characters of Jean Rhys not only appear as destitute women leading melancholy and precarious lives, but, I will argue, also display a fundamental reluctance to making a home and building a coherent narrative, in a world that denies their status as exceptions rather than mere anecdotal existences.

Repetition constitutes another such aesthetic means whereby Jean Rhys refuses to articulate her narratives through syntagm and hierarchy. By relying on reiteration, rather than iteration, she stands clear of any modernist attempt at "creative repetition", or "repetition with a change". Her writing combines narrative stasis with semantic and syntactic repetition, as well as recycled images. Repetition as a device has 
been called by some critics "Rhys's dissident statement" (Maurel 25), which is further exemplified in Rhys's signature address to a forever inexistent "you" throughout her novels: "that's the happy life when you don't care any longer if you live or die" (GMM 75). Rather than a reiterated lament about the characters' own unsatisfactory life and the helpless return to the same bleak rooms and precarious situations, ${ }^{26}$ or rather than anything as definite as boredom, I read repetition as insistence rather than complaint, as the means of a "neutral" distancing from the very standards of both European life and European novel-writing, or, as Blanchot has it, "an action of inaction" (Blanchot 305). In this light, the repetitive temporality appears as the active impossibility of creating a "story" or building a narrative because of the deliberate absence of anything special, or anything other.

One question remains to be addressed with respect to exception in Rhys's writing, and that is the occurrence, in her texts, of sudden, unexpected, exceptional comparisons and metaphors, that stand out against the monochrome background. Bizarre, incongruous images break the uniform surface of her laconic texts and create jarring notes that sometimes border on the expressionistic: ${ }^{27 "} \mathrm{~A}$ man and a girl were leaning against the railing in Brunswick Square, kissing. They stood without moving in the shadow, with their mouths glued together. They were like beetles clinging to the railings" (VD 30). Such uncanny images, both because they are not congruent with the general lack of ornamentation in Rhys's writing and because they are so crude, intermittently disrupt the narrative's uniformity that might otherwise become a regular and predictable pattern, while always avoiding becoming an organizing principle. Indeed, Rhys's use of the incongruous, because it is exceptional and because it brings unease to the reader and introduces opacity in the language, also stands for a "counter-discourse" ${ }^{28}$ within the general context of the narrative, especially when it serves to satirize the symbols of oppression: "A lady-some words have a long, thin neck that you'd like to strangle" (VD 120). ${ }^{29}$

In fact, Rhys's "sustained attack on Englishness and its proprieties" (Carr 14) is also directed at the English language as the language of imperialistic, patriarchal, linguistic, discursive hegemony. ${ }^{30}$ The destitution and disempowerment of its pompous potentialities, and exceptions to it, produces an "oblique" voice which some critics have recently called Rhys's "specifically Caribbean modernism" (Taylor-Batty 92) ${ }^{31}$ in the wake of Simon Gikandi's early definition of "Caribbean Modernism" as "radically different from 'high' modernism" (Gikandi 254). ${ }^{32}$ Indeed, in Rhys's own version of modernism, the well-known modernist trope of stylistic bareness and lack of ornamentation takes part in a "creolising linguistic [process]" (Taylor-Batty 92), in which reserve and laconicism might at times be read as a subversive mimicking of the creole cliché of passivity, but also as a linguistic process that opposes any exceptionalist ideology. ${ }^{33}$ The subjective withdrawal of Rhys's characters into "quasiabsence" (Blanchot 303) contaminates the English language itself and turns it into a disempowered version of itself. Stripped bare of its emphatic potentialities, it is reduced to its simplest unemphatic expression, forging a new language that challenges current linguistic and literary categories.

Jean Rhys's aesthetics takes us far beyond the question asked by Peter Childs, himself drawing on Patrick Williams (Williams 25), about Mansfield and Rhys: are they to be seen as "forging a distinct modernism or as inserting imperial history into metropolitan modernism" (Childs 2007, 38)? In the case of Jean Rhys, the two 
dimensions blend inseparably in her writing. Her engagement with experimentation in order to break from the codified constraints of literary norms is also an "oblique" political anti-imperialistic statement. Her inconspicuous exceptionality allows her a double vision epitomized by the picture bought by Sasha Jansen in Good Morning, Midnight, representing a man standing in the gutter and playing the banjo, "doubleheaded, double-faced" (GMM 91). This image can be seen as a symbol of Rhys's humble, synchronic and Cubist double perspective, and of her identity beyond the dichotomy that is often associated with her. Indeed, on an interestingly transnational scale, her disconcertingly subdued use of language might appear as a harbinger of French postwar literature, such as Albert Camus's or Marguerite Duras's "white writing" (écriture blanche). Instead of encouraging us to desperately try and place Jean Rhys, her exceptional case requires, instead, a redefinition of modernism and its canon. In an era of racing globalism, Jean Rhys calls her readers to the task of reading outside the set categories and lending their ears to what stories of exceptionality mongrels, black sheep and all kinds of "strange" exceptions like her might have to tell us.

\section{BIBLIOGRAPHY}

Athill, Diana. “Editing Jean Rhys.” Women: A Cultural Review 23:4 (2012): 401-407.

Benstock, Shari. Women of the Left Bank, Paris: 1900-1940. Austin: University of Texas Press, 1988.

Berman, Jessica. "Comparative Colonialisms: Joyce, Anand, and the Question of Engagement." Modernism/modernity 13:3 (2006): 465-485.

---. Modernist Commitments: Ethics, Politics, and Transnational Modernism. New York: Columbia University Press, 2011.

Blanchot, Maurice. The Infinite Conversation. Transl. Susan Hanson. Minneapolis and London: University of Minnesota Press, 1993.

Bowlby, Rachel. “The Impasse: Jean Rhys' Good Morning Midnight". Still Crazy After All These Years: Women. Writing and Psychoanalysis. London: Routledge, 1992.

BROWN, Nancy Hemond. “Aspects of the Short Story: A Comparison of Jean Rhys's 'The Sound of the River' with Ernest Hemingway's ‘Hills Like White Elephants'.” Jean Rhys Review 1:1 (1986):

2-12.

Brathwaite, Kamau. “A Post-Cautionary Tale of the Helen of Our Wars.” Wasafiri 22 (1995): 69-81.

Carr, Helen. Jean Rhys. 1992. London: Northcote House, 2012.

Childs, Peter. Modernism. New York: Routledge, 2000.

---. Modernism and the Post-Colonial. Literature and Empire 1885-1930. London: Continuum, 2007.

Delourme, Chantal. "Material Means: Forms of Precarious Life in Jean Rhys's Good Morning, Midnight.” L'Atelier 5:1 (2013): 16-30.

Emery, Mary Lou. “The Poetics of Labor in Jean Rhys's Caribbean Modernism”. In Women: A Cultural Review. Reading Jean Rhys 23:4 (2012). 421-444. 
---. "Foreword". In Rhys Matters: New Critical Perspectives. Ed. Kerry Johnson and Mary Wilson. New York: Palgrave Macmillan, 2013.

---. Jean Rhys at "World's End": Novels of Colonial and Sexual Exile. Austin: University of Texas Press, 1990.

Ford, Madox Ford. "Preface to 'Selection of Stories from The Left Bank”'. In Tigers are Better Looking with a Selection from The Left Bank, by Jean Rhys. 1927. London: André Deutsch, 1983.

Friedman, Susan Stanford. "Periodizing Modernism: Postcolonial Modernities and the Space/ Time Borders of Modernist Studies." Modernism/modernity 13:3 (2006): 425-443.

Gardiner, Judith Kegan. “Good Morning, Midnight; Good Night, Modernism”. Boundary 2. 11:1/2 (1982-1983): 233-251.

Gikandi, Simon. Writing in Limbo: Modernism and Caribbean Literature. Ithaca (N.Y.): Cornell University Press, 1992.

Hulme, Peter. "The Locked Heart: The Creole Family Romance of Wide Sargasso Sea”. In Colonial Discourse, Postcolonial Theory. Ed. Francis Barker et al. Manchester: Manchester University Press, 1994. 72-88.

---. "The Place of Wide Sargasso Sea". Wasafiri 10:20 (1994): 5-11.

Johnson, Erica L. Home, Maison, Casa. The Politics of Location in Works by Jean Rhys, Marguerite Duras, and Erminia Dell'Oro. London: Associated University Presses, 2003.

Johnson, Erica and Patricia Moran. "Introduction: The Haunting of Jean Rhys". In Jean Rhys: Twenty-First Century Approaches. Edinburgh: Edinburgh University Press, 2015. 1-18.

Johnson, Erica and Elaine Savory (eds.). Wide Sargasso Sea at Fifty. New York: Palgrave Macmillan, 2020 .

Johnson, Kerry and Mary Wilson (eds.). "Introduction”. In Rhys Matters: New Critical Perspectives. Ed. Kerry Johnson and Mary Wilson. New York: Palgrave Macmillan, 2013.

Joubert, Claire. Lire le féminin. Paris: Messene, 1997.

Joyce, James. “Eveline”. In Dubliners. 1914. London: Penguin, 2000. 29-34.

Kalliney, Peter. "Jean Rhys: Left Bank Modernist as Postcolonial Intellectual”. In The Oxford Handbook of Global Modernisms. Eds. Mark Wollaeger and Matt Eatough. Oxford: Oxford University Press, 2012. 413-32.

Mansfield, Katherine. "Pictures". 1920. In Selected Stories. Oxford: Oxford University Press, 1981. 141-153.

Maurel, Sylvie. Jean Rhys. London: Macmillan, 1998.

McCracken, Scott. “Strange Defeat: Good Morning, Midnight and Marc Bloch's L'Étrange Défaite”. Transnational Jean Rhys: Lines of Transmission, Lines of Flight. Ed. Juliana Lopoukhine, Frédéric Regard and Kerry-Jane Wallart. New York: Bloomsbury, 2020. 35-49.

Mignolo, Walter D. "DELINKING. The Rhetoric of Modernity, the Logic of Coloniality and the Grammar of De-coloniality”. Cultural Studies 21:2-3 (2007): 449-514.

Moran, Patricia. Virginia Woolf, Jean Rhys, and the Aesthetics of Trauma. New York: Palgrave Macmillan, 2007.

Naipaul, V.S. "Without a Dog's Chance”. The New York Review. 18 May 1972. Accessed 30 October 2020. <https://www.nybooks.com/articles/1972/05/18/without-a-dogs-chance/> 
Owen, Katie. “Introduction”. In Quartet. Jean Rhys. London: Penguin. 2000, v-xviii.

Phillips, Caryl. A View of the Empire at Sunset. London: Vintage, 2018.

Rhys, Jean. After Leaving Mr Mackenzie. London: Penguin, 2000. (ALM)

---. Voyage in the Dark., London: Penguin. 2000. (VD)

---. Good Morning, Midnight. London: Penguin. 2000. (GMM)

---. Wide Sargasso Sea. Ed. Judith Raiskin. New York: Norton, 1999.

---. Smile Please: An Unfinished Autobiography. London: Penguin, 1990. (SP)

---. Jean Rhys: Letters 1931-66. Ed. Francis Wyndham and Diana Melly. Harmondsworth: Penguin, 1985. (Letters)

Rovera, Catherine. Genèses d'une folie créole. Paris: Hermann, 2015.

Savory, Elaine. Jean Rhys. Cambridge: Cambridge University Press, 1998.

---. "Preface". The Cambridge Introduction to Jean Rhys. Cambridge: Cambridge University Press, 2009. ix-xi.

Scott, Bonnie Kime (ed). The Gender of Modernism: A Critical Anthology. Bloomington: Indiana University Press, 1990

Snaith, Anna. “'A Savage from the Cannibal Islands', Jean Rhys and London”. In Geographies of Modernism. Ed. Peter Brooker and Andrew Thacker. London and New York: Routledge, 2005. 76-85.

Taylor-Batty, Juliette. Multilingualism in Modernist Fiction. London: Palgrave Macmillan, 2013.

Thacker, Andrew. “'Also I do like the moderns': Reading Rhys's reading”. In Transnational Jean Rhys: Lines of Transmission, Lines of Flight. Ed. Juliana Lopoukhine, Frédéric Regard and Kerry-Jane Wallart. New York: Bloomsbury, 2020. 51-64.

---. Modernism, Space and the City: Outsiders and Affect in Paris, Vienna, Berlin and London. Edinburgh: Edinburgh University Press, 2019.

---. Moving Through Modernity: Space and Geography in Modernism. Manchester and New York: Manchester University Press, 2003, 2009.

Thomas, Sue. “Jean Rhys and Katherine Mansfield Writing the 'sixth act"'. In Jean Rhys: TwentyFirst Century Approaches. Eds. Erica L. Johnson and Patricia Moran. Edinburgh: Edinburgh University Press, 2015. 21-39.

Wallart, Kerry-Jane. “'The small things that they've not been able to talk about': An interview with Caryl Phillips about his novel A View of the Empire at Sunset (2018)". In Transnational Jean Rhys: Lines of Transmission, Lines of Flight. Ed. Juliana Lopoukhine, Frédéric Regard and Kerry-Jane Wallart. New York: Bloomsbury, 2020. 177-186.

Williams, Patrick. “'Simultaneous Uncontemporaneities': Theorising Modernism and Empire.” In Modernism and Empire. Ed. Howard J. Booth and Nigel Rigby. Manchester: Manchester University Press, 2000.

\section{NOTES}

1. Savory refers to Barbadian poet and academic Kamau Brathwaite's phrase about Jean Rhys: "the Helen of our wars" (Brathwaite 69). 
2. Although Jean Rhys was included in Bonnie Kime Scott's 1990 anthology Gender and Modernism, it is striking to note that she is only mentioned in passing in much more recent books like Peter Childs's Modernism (2000) and Modernism and the Post-Colonial (2007), as opposed to Katherine Mansfield who is featured more extensively, and although the latter book is explicitly devoted to two of the cultural fields that have a claim to Jean Rhys as a writer.

3. Although other modernists such as Katherine Mansfield or James Joyce share Rhys's status as colonial subjects, what makes the latter's position different from theirs might be in part the fact that she didn't have a say in the decision that made her leave the island of Dominica to live in Europe instead, at a young age and out of necessity.

4. See Susan Stanford Friedman's 2006 essay "Periodizing Modernism: Postcolonial Modernities and the Space/Time Borders of Modernist Studies". See also Walter Mignolo's 2007 influential essay "Delinking: the Rhetoric of Modernity, the Logic of Coloniality and the Grammar of Decoloniality". See Peter Kalliney's 2012 essay entitled “Jean Rhys: Left Bank Modernist as Postcolonial Intellectual" in which he discusses the influences and relationships between interwar Anglo-Saxon modernism and post-war late colonial and post-colonial literature. This is in line with Simon Gikandi's 1992 urge to consider "modernity and modernism from the margins of the modern world system" which in turn "forces us to question previous definitions of the term itself and to recognize its variegated genealogies and contradictory categories." (Gikandi 254)

5. A term I borrow from Mary-Lou Emery (Emery 2013, xi).

6. Jean Rhys's first novel, Quartet (1929), is not included in this study, as the political aspect of Rhys's use of experimental modes of writing seems to be more acutely felt in her later interwar work, an opinion shared by the author of the introduction to Quartet in the 2000 Penguin edition: "in her later work, there grows a sense of social awareness and perspective" (Owen xvii).

7. See Helen Carr's account of the prejudiced early understanding of Rhys: "intuitive more than intelligent, feeling rather than thinking" (Carr 9).

8. See Maurel's detailed account of the impact of Wide Sargasso Sea on Rhys's writing career: “It brought Jean Rhys recognition, prizes and money. Her novels were all reissued, while some of her new stories were published [...]. She was made a Fellow of the Royal Society of Literature and a CBE." (4)

9. Johnson and Moran, however, see Wide Sargasso Sea as "relevant to modernist stylistics" (3), an assessment that potentially appears as one more challenge to the temporal and spatial coordinates of modernism.

10. See Rhys's editor Diana Athill's moving testimony about Rhys's writing process in the later part of her career (Athill 2012).

11. See Savory's account of the academic debate about her between Peter Hulme and Kamau Brathwaite (216).

12. Shari Benstock explicitly makes Rhys an exception among other writers and even other women writers who lived in Paris during the modernist period: geographically, because she had several different lodgings in the $13^{\text {th }}$ arrondissement, close to the prison de la Santé where her husband was detained, rather than in fashionable Montparnasse; socially, because she shunned literary circles; literarily, because she chose topics that were different (Benstock 449).

13. On Jean Rhys's identical hotel rooms and repetitive temporality as "impasse", see Rachel Bowlby's essay “The Impasse: Jean Rhys' Good Morning Midnight”.

14. See Anna Snaith's analysis of the "repeated images of metropolitan uniformity" (Snaith 76) in Voyage in the Dark as a will for the first-person narrator to "assert herself as a unique West Indian from a unique island." (Snaith 80)

15. Snaith calls it a "refrain" (Snaith 80).

16. On "the stasis and repetitiveness of England", as "entrapment", see Erica L. Johnson 79. 
17. A comparable temporal, spatial and narrative stasis is to be found, for instance, in James Joyce's short story "Eveline" in which the main character, who remains motionless for most of the narrative, seems trapped in a temporal maze from which she cannot escape to a different place that would ensure her independence from her father-and, contrary to Rhys's character, from her home country. Some of Katherine Mansfield's short stories also present a labyrinth-like relationship to space, such as "Pictures" in which the main character Ada Moss is constantly moving from one place in the city to another in quest of a job as a singer, only to end up with nothing. However, contrary to Rhys's characters, a genuine disappointed desire is to be found in Ada Moss, as in other characters in Mansfield's stories.

18. I am indebted to the peer-reviewing process of this article for pointing out the echo with Gertrude Stein's emblematically experimental phrase "a rose is a rose is a rose".

19. See Andrew Thacker's study of the "cartographic representations of space" that are "always problematical" in Rhys's novels (Thacker 2009, 212) and his recent study of Rhys's Paris (Thacker 2019).

20. In his recent book Modernism, Space and the City, Andrew Thacker has entitled the section dedicated to Rhys “Jean Rhys: Being Faithful to Paris" (Thacker 2019, 45).

21. Perhaps it is worth remembering, as Anna Snaith has noted, that Dominica, the island Jean Rhys came from, was "an object of exchange between the French and British" (Snaith 76).

22. A more detailed investigation into the stylistic common points and differences between Rhys and other modernist writers deserves to be conducted in future research on Jean Rhys. Several critics have already paved the way by attempting such comparisons: on a reading of Rhys's style against Hemingway's, see Brown's 1986 article and, more recently, Andrew Thacker's comparison of Rhys's and Hemingway's Paris (Thacker 2019, 48-49); on Jean Rhys and Katherine Mansfield, see, among others, Sue Thomas's 2013 essay; on Rhys and Woolf, see, among others, Patricia Moran's 2007 book, Jessica Berman's book chapter entitled “Intimate and Global: Ethical Domains from Woolf to Rhys" (Berman 2011, 39-89), and also Rachel Bowlby (52-57) and Judith Kegan Gardiner (244-246). I am indebted to the anonymous review of this article for pointing out Judith Kegan Gardiner's reading of the ironical echoes of James Joyce's Ulysses in some passages of Good Morning, Midnight, particularly the ending (Gardiner 247-49).

23. If other modernist writers have touched on the theme of the unexceptional as resistance to the narrative norm, or have developed experimental linguistic forms linked to their status as colonial subjects, several critics have underlined the fact that these forms of experimentation could not have the same meaning as Rhys's, because of her combination of gender and white creole identity. See especially Savory (Savory 1998, 199, 224). Naipaul wrote in 1972 that Rhys stood "outside that tradition of imperial-expatriate writing in which the metropolitan outsider is thrown into relief against an alien background." (Naipaul 1972) In a recent essay, Andrew Thacker writes: "Rhys was an outsider to the European 'tradition' proposed by Eliot and was thus a resistant reader of that tradition." (Thacker 2020,55)

24. See Rachel Bowlby's reading of this phrase in relationship with "the identical sameness of a cliché" (Bowlby 37).

25. See Judith Kegan Gardiner's reading of Woolf's and Rhys's contrasting visions of the "room of one's own" (Gardiner 245).

26. See Chantal Delourme's work on precariousness in Good Morning, Midnight (Delourme 2013).

27. Claire Joubert writes about how Rhys builds a "network of tortured images in the expressionistic style" (Joubert 197, translation mine).

28. For this expression I am indebted to Helen Carr (Carr 77).

29. Anna Snaith sees this sentence as "retaliatory linguistic violence" (Snaith 82).

30. In a recent interview with Kerry-Jane Wallart about his 2018 novel based on Jean Rhys's life, Caryl Phillips declared that for Rhys, "using the French language involved [...] a temporary escape from the judgemental nature of English and Englishness." (Wallart 2020) 
31. A phrase also used by Mary-Lou Emery in the title of a 2012 essay on Jean Rhys.

32. Gikandi sees "Caribbean Modernism" as "highly overdetermined by history, which it seeks to confront rather than escape" as well as "closely implicated in political and economic theories of modernization." (Gikandi 254)

33. See Peter Hulme's examination of the term "creole", and of the clichés associated with it, in relationship to Wide Sargasso Sea (Hulme 1994a). In a different essay, Peter Hulme discusses the forms of "non-standard" and "creolised" English in Wide Sargasso Sea, as opposed to "Englishness as a construct" (Hulme 1994b). See also Catherine Rovera's analysis of the creolization of Rhys's writing in Wide Sargasso Sea and subsequent linguistic hybridity. (Rovera 42-50)

\section{ABSTRACTS}

When it comes to modernist exceptions, Jean Rhys appears as a particularly striking case in point: her marginality as a white creole woman writer who shunned the literary circles in both Paris and London, her notably twisted editorial history, her disappearance for twenty-five years and the retrospective rediscovery, in the 1960s, of her interwar texts, have sparked an ongoing debate about the question of her place in the modernist canon. Her experimental poetics, which was acknowledged as exceptional by Ford Madox Ford as early as 1927, is characterized by a sense of jaded experience, the juxtaposition of indifferent and even interchangeable places and people, as well as a semantic and syntactic minimalism based on repetition. The aim of this article is to show how Jean Rhys's exceptionality as a modernist writer relies as much on her canonical unplaceability as, paradoxically, on her aesthetics of the unexceptional.

Lorsque l'on parle d'« exceptions modernistes », l'exemple de Jean Rhys frappe par sa singularité : sa marginalité en tant que femme écrivain et «créole blanche » qui, à Londres comme à Paris, se tenait à l'écart des cercles littéraires; les tours et détours notoires de sa fortune éditoriale ; sa disparition pendant vingt-cinq ans ; la redécouverte rétrospective, dans les années 1960 , de ses textes écrits dans l'entre-deux-guerres ; tout cela a donné lieu à un débat toujours actuel au sujet de sa place dans le canon moderniste. Son écriture expérimentale, saluée comme exceptionnelle dès 1927 par Ford Madox Ford, est marquée par une tonalité désabusée, une indifférence subjective aux lieux et aux personnages, juxtaposés jusqu'à devenir interchangeables, ainsi que par une pauvreté sémantique et syntaxique fondée sur la répétition. Cet article se propose de montrer comment le caractère exceptionnel de Jean Rhys en tant qu'écrivain moderniste s'appuie tout autant sur sa marginalité par rapport au canon que, paradoxalement, sur son esthétique du non exceptionnel.

\section{INDEX}

Mots-clés: Jean Rhys, modernisme, canon moderniste, expérimentation, répétition, exception, anecdote, désenchantement, Caraïbe, Antilles

Keywords: Jean Rhys, Modernism, modernist canon, experimentation, repetition, exception, unexceptional, anecdote, disenchantment, Caribbean, West Indies 


\section{AUTHORS}

\section{JULIANA LOPOUKHINE}

Maîtresse de conférences

Sorbonne Université, Paris

j_lopoukhine@yahoo.fr 